\section{The potential of strategic environmental assessment to reduce disaster risks through climate change adaptation in the coastal zone of Bangladesh}

\author{
Md. Suzaul Islam and Yanrong Zhang \\ School of Environmental Science and Engineering, \\ Huazhong University of Science and Technology, Wuhan, China
}

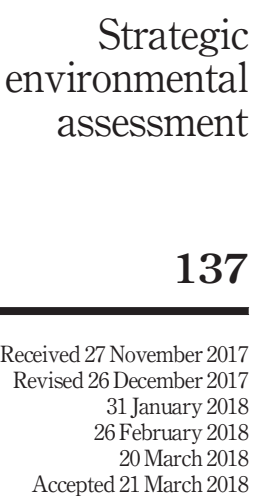

Accepted 21 March 2018

\begin{abstract}
Purpose - The purpose of this paper is to analyze the potential of strategic environmental assessment (SEA) to mainstream consideration of climate change adaptation (CCA) in Bangladesh, particularly for the coastal zone, to improve disaster risk reduction (DRR) strategies in this region. Continuing climate risks require adaptation at all levels of society. The densely populated and resource-rich coastal zone of Bangladesh is at risk to the impacts of climate change.

Design/methodology/approach - This research is based on secondary sources (gray and published literature) of information on climate change impacts on the coastal zone of Bangladesh. The sources include research reports, online publications, governmental reports, scientific journals, international reports, books, journal articles and other academic resources on SEA, climate change adaptation and mitigation, and DRR. In addition to examining SEA in Bangladesh, this paper investigates SEA cases in different countries to obtain insights from the successful application of SEA for CCA.

Findings - The paper draws on several cases from different countries demonstrating that SEA has a significant potential to coordinate CCA objectives. The findings reveal that the appropriate use of SEA can enable DRR through CCA.
\end{abstract}

Originality/value - This study argues that SEA has a potential role in supporting CCA.

Keywords Bangladesh, Disaster risk reduction, Climate change, Coastal zone,

Strategic environmental assessment

Paper type Research paper

\section{Introduction}

The developing country of Bangladesh is among the most susceptible to the impacts of extreme climate change because of its biophysical (deltaic coastal, low-lying, flat topography, frequent cyclones and flooding) and socio-economic characteristics (agricultural dependence, poverty and high population density; Climate Change Profile: Bangladesh, 2016). The frequency of disasters such as floods, cyclones, river bank erosion, typhoons, salinity intrusions and tidal surges is gradually increasing as a result of climate

(C) Md. Suzaul Islam and Yanrong Zhang. Published by Emerald Publishing Limited. This article is published under the Creative Commons Attribution (CC BY 4.0) licence. Anyone may reproduce, distribute, translate and create derivative works of this article (for both commercial and noncommercial purposes), subject to full attribution to the original publication and authors. The full terms of this licence may be seen at http://creativecommons.org/licences/by/4.0/legalcode

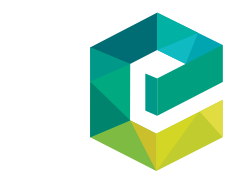

International Journal of Climate Change Strategies and Vol. 11 No. 1, 2019

pp. 137-153
Emerald Publishing Limited $1756-8692$
shing Limited DOI 10.1108/IJCCSM-11-2017-0201 
IJCCSM 11,1

change, in turn, increasing the danger and risks for populations in the coastal area of Bangladesh. Future increases in these and other adverse impacts of climate change will severely affect the coastal ecosystem and human health and safety. A long term-policy for government planning is required to reduce the risk of disaster by addressing the impacts of climate change.

This paper focuses on the potential of strategic environmental assessment (SEA) to enhance disaster risk reduction (DRR) strategies for the coastal zone of Bangladesh by integrating climate change adaptation (CCA). This paper provides an account of the role of SEA as an integral component of policy and decision-making and its contribution to CCA. SEA case studies with a potential role in CCA are identified. A review of the literature and SEA cases suggests that systematic and organized applications of SEA may generate an alternative solution for DRR through CCA.

Leary (2012) reported that:

[...] we can either adapt to climate change and reduce its impacts, or we can fail to adapt and expect much more serious consequences. The future will be shaped according to our response to this challenge.

The United Nations' Sustainable Development Goals emphasize the need for multidisciplinary, coordinated attempts to limit the increase in global temperature to $1.5^{\circ} \mathrm{C}$ $2^{\circ} \mathrm{C}$ and prevent the disastrous consequences of climate change (Quam et al., 2017; An Action Agenda for Sustainable Development, 2015). Reducing hazards as well as exposure to current climate change is the first step in adapting to future climate change. Flooding and severe events will become more prevalent with climate change (Ghofrani et al., 2017), and simple sustainable approaches, such as SEA, may be key strategies for integrating processes to address CCA.

According to the Intergovernmental Panel on Climate Change's (IPCC) Fifth Assessment Report (AR5), global sea levels will continue to rise in the twenty-first century, possibly at a faster rate than between 1971 and 2010. However, sea level increases will not be the same in all regions. By the end of the twenty-first century, it is "very likely" that sea levels will increase in more than 95 per cent of the ocean's area. Worldwide, approximately 70 per cent of coastlines are projected to experience sea level changes of \pm 20 per cent of the global mean (IPCC, 2014). Climate change will increase current risks and create new risks for human and natural systems. These risks are unequally distributed and are usually greater for disadvantaged people and communities in countries at every level of development (IPCC, 2014). In South Asia, the IPCC's AR4 (Fourth Assessment Report) (IPCC, 2007) predicts that monsoon rainfall will rise, resulting in higher flows in river systems throughout the monsoon season. Sea levels are predicted to increase by $0.18-0.79$ meters, which will lead to coastal flooding and salinity intrusion. Rainfall is expected to become more erratic and higher in volume.

Environmental impact assessment (EIA) is likely inherently unsuitable as a primary means of tackling climate change (Christopher, 2008). According to Alshuwaikhat (2005), "despite the existence of good EIA guidelines and legislation, environmental degradation continues to be a major concern in developing countries". EIA has not been able to provide "environmental sustainability assurance" for these countries (Alshuwaikhat, 2005; Alshuwaikhat et al., 2007; Sadler, 1999). Many authors have recognized that SEA can play a role in integrating environmental factors into policy, plan and program (PPP) decisionmaking procedures, thus contributing to sustainability (Noble and Storey, 2001). In contrast to well-developed EIA procedures for specific projects/actions, SEA is a new concept in developing countries (Gao, 2017). Plans usually have a more profound and cumulative 
impact on climate change mitigation and adaptation than site-specific projects (Christopher, 2008).

The lack of well-established methodologies for determining the impact of climate change is a key problem. Previous studies of the impact of climate change in Bangladesh have suffered from a lack of structured research, and the use of SEA to reduce the disaster risk, resulting from the impacts of climate change has received little attention. Moreover, relevant data and resources for SEA of PPP require further development. These deficiencies highlight the need for more research on the coastal zone of Bangladesh to enable the incorporation of climate change impacts in PPPs by applying SEA for DRR.

The paper explores the integration of CCA and DRR with the use of SEA. An overview is provided of the coastal zone of Bangladesh and the potential climate change impacts in coastal areas. This study advocates SEA and its implications for CCA and examines the SEA position of Bangladesh. Cases of SEA are presented, and core challenges for the application of SEA to ensure the integration of CCA and DRR are addressed.

\section{Overview of the coastal zone of Bangladesh}

The coastal zone of Bangladesh encompasses a land area of $47,201 \mathrm{~km}^{2}$. The local population was 36.8 million in 2001, an increase of 8.1 million from a century earlier, and is projected to increase to approximately 43.9 million in 2015 and 60.8 million in 2050 (Ahmed and Suphachalasai, 2014). The coastal zone covers 19 of 64 districts along or near the Bay of Bengal, including approximately 153 geographic administrative regions known as upazilas (MoWR, 2006). Only 12 of these 19 districts directly meet the sea or lower estuary. Figure 1 presents a map of the coastal zone of Bangladesh.

\section{Strategic environmental assessment}

Source: Chowdhury (2015)
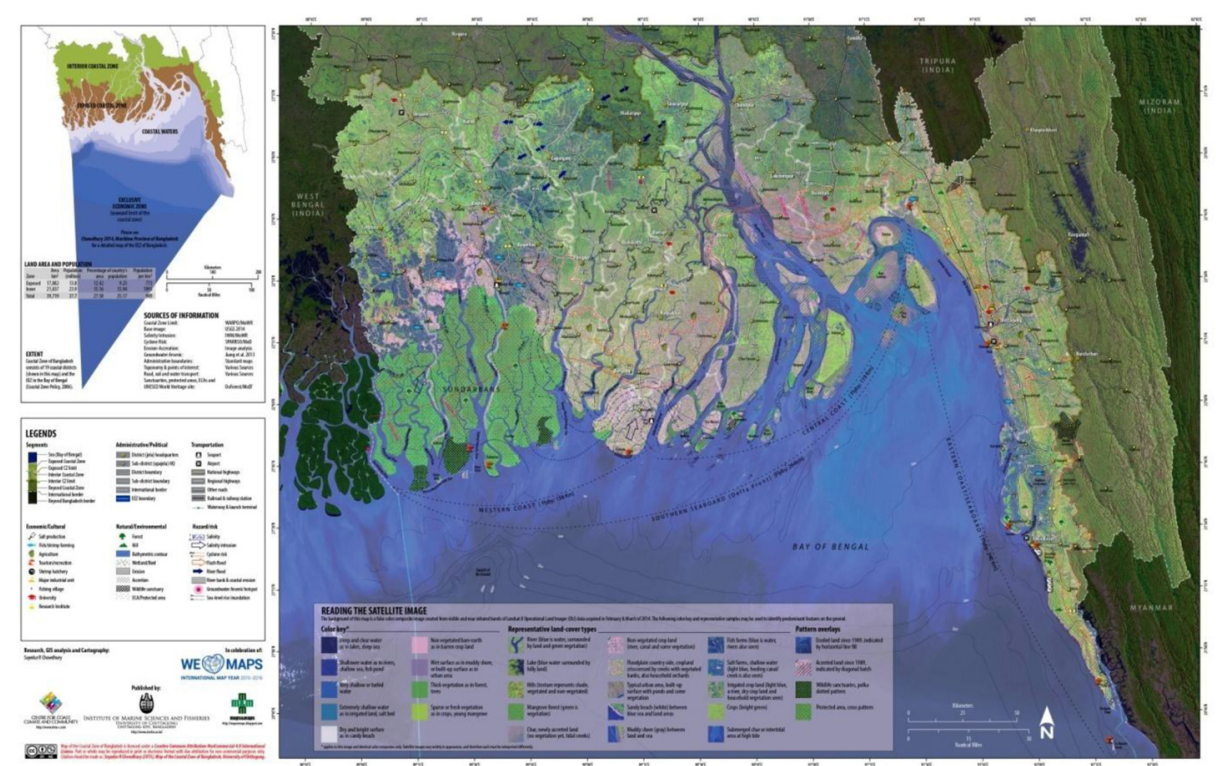

Figure 1. Map of the coastal zone of Bangladesh 
IJCCSM 11,1

Pramanik (1983) separated the coastal area into three coastal zones: western, central and eastern (Hossain et al., 2009; BBS, 2015). The western coastal zone is concealed by the Sundarbans, the world's largest mangrove forest, which covers the districts of greater Khulna, Satkhira and Bagerhat. The mangrove area supports breeding and feeding grounds for shrimp and fish species, enriching fishery biodiversity. The western coastal zone provides a variety of goods and services to the people of Bangladesh. The central coastal zone stretches from the Feni river estuary to the eastern corner of the Sundarbans and includes the districts of Noakhali, Bhola, Barisal Barguna, Jhalokati, Pirojpur and Patuakhali. This area features many islands, including the country's only island district, Bhola. The central coastal zone receives a large volume of discharge from the MeghnaBrahmaputra-Ganges river system, resulting in high quantities of silt deposition. The eastern coastal zone stretches from Bodormokam at the southern tip of the mainland to Teknaf and the Feni river estuary and includes the districts of Noakhali, Chittagong and Cox's Bazar. Fishing in the bay, fish farming, tourism and salt production are the major economic activities in the eastern coastal zone (BBS, 2015).

\section{Potential impacts on the coastal zone}

The adverse impacts of climate change, including impacts on economic growth and poverty, are more severe in the coastal area than in other areas. Natural hazards increase the vulnerabilities of coastal citizens and slow economic and social development, particularly in the southwestern region. As recognized by IPCC's AR4 (2007), the National Adaptation Program of Action (NAPA, 2005) and others, the coastal zone of Bangladesh is among the most vulnerable regions in the country and the world to the recurrent threats of climate change and coastal hazards (Parvin et al., 2010). The three zones of the coastal area are susceptible to a variety of natural hazards, including cyclone and storm surges, land erosion, floods, water logging, salinity intrusions, drought, earthquake, arsenic contamination and shortages of drinking water, ecosystem degradation, pollution, and sea level rise (Parvin et al., 2010; Islam 2004, 2008). Table I provides a brief summary of the various hazards and vulnerable regions in the coastal zone of Bangladesh.

Among the natural hazards faced by coastal belt populations, cyclones and floods have the greatest direct impact on communities and livelihoods. Major destructive cyclones have caused extensive damage and massive deaths of people and livestock in coastal areas. According to Wang et al. (2016), Agee et al. (2016) and Elsner et al. (2015), a significantly warmer climate may lead to more frequent extreme storms, which may increase the public health burden. The floods of 1988, 1998 and 2004 were especially catastrophic, resulting in large-scale damage and loss of life (Aminuzzaman, 2014). According to Germanwatch (Kreft et al., 2015; BEFCCCIP, 2016), which compiles the Climate Risk Index based on the impacts of severe weather events in different countries, Bangladesh suffered an average annual loss of more than 700 lives and approximately $\$ 2.5$ billion, or 0.86 per cent of annual gross domestic product, over the period 1995-2014.

Beyond the human toll, the losses of natural resources, infrastructure and livestock due to natural disasters are particularly devastating for a developing country like Bangladesh. Walsham (2010) showed that global warming would affect those living in the coastal regions of Bangladesh for generations, increasing refugee and homeless populations. Given this risk, an adaptation strategy for the impacts of climate change considering regions and populations at risk must be adopted by the Government of Bangladesh (GoB). 


\begin{tabular}{|c|c|c|c|}
\hline Type of hazard & Vulnerable regions & Remarkable incidents & $\begin{array}{l}\text { Strategic } \\
\text { ronmental }\end{array}$ \\
\hline $\begin{array}{l}\text { Cyclone and storm } \\
\text { surges }\end{array}$ & $\begin{array}{l}\text { Exposed upazilas, islands, and the } \\
\text { central coast }\end{array}$ & $\begin{array}{l}\text { At least } 70 \text { major cyclones have hit the } \\
\text { coastal region in the last } 200 \text { years, killing } \\
\text { approximately } 900,000 \text { people. In the Bay of } \\
\text { Bengal, } 6 \text { tsunamis have been recorded in } \\
\text { the past } 250 \text { years }\end{array}$ & assessment \\
\hline Land erosion & $\begin{array}{l}\text { Meghna and other estuaries, coastal } \\
\text { rivers and islands }\end{array}$ & $\begin{array}{l}86,366 \text { ha of land eroded in the Meghna } \\
\text { estuary between } 1973 \text { and } 2000\end{array}$ & 141 \\
\hline $\begin{array}{l}\text { Floods (mainly tidal } \\
\text { floods) }\end{array}$ & Exposed islands & $\begin{array}{l}\text { To protect the coastal region, } 123 \text { polders } \\
\text { with an embankment of } 5,017 \mathrm{~km} \text { have been } \\
\text { built }\end{array}$ & \\
\hline \multirow{2}{*}{$\begin{array}{l}\text { Water logging/ } \\
\text { drainage congestion }\end{array}$} & Jessore, Khulna (western coastal zone) & In 1993, the Khulna-Jessore Drainage & \\
\hline & $\begin{array}{l}\text { Noakhali, Patuakhali, Bhola, Barguna } \\
\text { and Pirojpur districts }\end{array}$ & $\begin{array}{l}\text { Rehabilitation Project was established with } \\
\text { funding from ADB. In } 2007 \text {, an evaluation } \\
\text { report by ADB found that the project had } \\
\text { failed in many respects }\end{array}$ & \\
\hline Salinity intrusions & Western exposed upazilas & $\begin{array}{l}\text { In the southwestern region, } 70 \% \text { of } 2.35 \\
\text { million ha of agricultural land are affected } \\
\text { by soil salinity }\end{array}$ & \\
\hline \multirow[t]{2}{*}{ Droughts } & Satkhira (western coastal zone), Khulna, & A small number of districts in the & \\
\hline & Bagerhat and Pirojpur districts & $\begin{array}{l}\text { southeastern coastal area face extreme } \\
\text { drought during Kharif (June/July to October) }\end{array}$ & \\
\hline Earthquakes & Chittagong & $\begin{array}{l}\text { Although the coastal zones are less } \\
\text { susceptible to earthquakes, the incidence of } \\
\text { earthquakes has increased in recent times. } \\
\text { Since } 2000,40 \text { earthquakes have been } \\
\text { registered }\end{array}$ & \\
\hline $\begin{array}{l}\text { Arsenic } \\
\text { contamination and } \\
\text { drinking water } \\
\text { shortages }\end{array}$ & All over & $\begin{array}{l}\text { In coastal areas, approximately } 53 \% \text { of tube } \\
\text { wells are contaminated with arsenic over the } \\
\text { permissible level. At the national level, } 29 \% \\
\text { of tube wells have excessive arsenic }\end{array}$ & \\
\hline \multirow{2}{*}{$\begin{array}{l}\text { Ecosystem } \\
\text { degradation }\end{array}$} & Marine, the Sundarbans & The Sundarbans mangrove forest is a World & \\
\hline & & $\begin{array}{l}\text { Heritage site, but several species are } \\
\text { affected by diseases such as root rot, top- } \\
\text { dying and die back }\end{array}$ & \\
\hline Pollution & Khulna, Chittagong (sea port areas) & $\begin{array}{l}\text { Domestic effluents, oil spills and } \\
\text { dismantling of old ships ( } 90 \text { vessels per year } \\
\text { on average) have negatively impacted fauna } \\
\text { and flora and destroyed valuable } \\
\text { ecosvstems }\end{array}$ & Table I. \\
\hline Sea level rise & All over & $\begin{array}{l}\text { The coastal zone of Bangladesh is at major } \\
\text { threat from climate change. By } 2030 \text {, sea } \\
\text { levels are projected to increase by } 30 \mathrm{~cm} \text {, } \\
\text { with temperature rises of } 0.7^{\circ} \mathrm{C} \text { in the } \\
\text { monsoon season and } 1.3^{\circ} \mathrm{C} \text { in winter }\end{array}$ & $\begin{array}{r}\text { List of natural } \\
\text { hazards and } \\
\text { vulnerable regions in } \\
\text { the coastal zone of } \\
\text { Bangladesh }\end{array}$ \\
\hline
\end{tabular}

\section{Strategic environmental assessment and its role in climate change adaptation}

Sadler and Verheem (1996) defined SEA as follows:

SEA is a systematic process for evaluating the environmental consequences of proposed policy, plan or program initiatives in order to ensure they are fully included and appropriately addressed at the earliest appropriate stage of decision-making on par with economic and social considerations. 
IJCCSM 11,1

Willekens et al. (2011) reported that SEA is a useful instrument for facilitating decisionmaking on CCA, tackling problems and supporting CCA actions during the planning process. SEA can be used to assess the environmental impacts of adaptation strategies, including probable clashes with other existing national or regional plans and programs. SEA is a suitable tool for integrating CCA and DRR because it ensures that all mid- and long-term development planning, including spatial planning, incorporates the carrying capability of the environment, all environmental concerns and CCA in all regional and crosssector development to minimize the risk of disaster (Susilowardhani, 2014).

Examples of the use of SEA in planning can be found around the world. In Indonesia, the government of Semarang City began developing an SEA for spatial planning in 2011 to be performed by the Environmental Agency (BLH Kota Semarang) and the Development Planning Agency (BAPPEDA Kota Semarang). The aim was to examine the challenges of mainstreaming climate change concern, particularly in Semarang, to improve the DRR strategy in this region. The implementation of SEA at an early stage provided a framework for evaluating and managing environmental hazards and increased awareness of the urgency of integrating DRR and CCA in SEA for spatial planning, particularly in Semarang.

Other examples of the successful application of SEA in spatial planning can be found in Austria (Stoeglehner, 2010), the Czech Republic (Smutný, 2014), the province of Naples in southern Italy (Geneletti et al., 2007) and Egypt (Hegazy, 2015). In South Africa, the coastal city of Durban implemented the Climatic Future for Durban Program, an integrated assessment framework that will provide strategic input on the continuing development of the city's Integrated Development Plan and allow Ethekwini Municipality to factor climate change concerns into its long-term planning and budgeting (Roberts, 2008). In Jamaica, SEA has been recognized as a useful instrument for mainstreaming DRR and CCA into national policies as well as policies for key sectors for development that are vulnerable to climate risks (physical development, fishery and agricultural sectors) (OECD/DAC, 2010).

According to OECD/DAC (2010), in exploring the role of SEA in CCA, it is significant to recognize three features: first, the need for detailed evidence of the current state of the climate in a specific country (science); second, the technological and institutional characteristics of the theme area exposed to climate change consequences (e.g. agriculture, water supply and human health); and third, the specific resources that the SEA procedure itself can provide in connecting science and technology with institutional concerns. A variety of scientific data, skills and procedures are needed to predict future climate change, including the ability to model both season and annual changes in weather at both the regional and national levels. Such models could play a role in SEA (particularly by involving indigenous communities in assessing current and past trends of climatic situations), albeit minor. In the majority of cases, SEA will simply draw on the results of the ongoing literature on climate change.

The most important functions of SEA are managing climate change consequences, evaluating the strategic response, and assessing and developing adaptive PPPs. How these concerns are handled depends on the specific situation of the country, such as its governance structure, public awareness level, level of local community involvement/public participation and nature of the political economy. The capacity of SEA to incorporate scientific appraisals with environmental, social and economic evaluations and generate objective and independent results using participatory methods make it one of the most successful processes for formulating a practical response to CCA. 


\section{Strategic environmental assessment position in Bangladesh}

In Bangladesh, SEA has no significant position in PPP because of the lack of a legal; institutional and political framework for SEA; and the lack of a requirement for short-, medium- or long-term development planning in addition to spatial planning. The existing policy framework that deals with the impacts of natural disasters is not adequate because it fails to successfully integrate all environmental factors, including those related to climate change. Consequently, to reduce the risks of disaster by addressing the impacts of climate change, it would be most appropriate for Bangladesh to use SEA in the planning process with integration of both CCA and DRR to protect the coastal zone as well as the country from natural hazards induced by the impacts of severe climate change.

Compared to other Least Developed Countries, Bangladesh has a relatively long history of studies of climate change and adaptation intervention (Ayres and Huq, 2009; Ayres et al., 2014). The country launched its National Adaptation Program of Action (NAPA) in 2005 and revised it in 2009 (Dyoulgerov et al., 2011). This program focused on the coastal zone, water, natural disasters, health, biodiversity, forestry, land use, agriculture, livestock, fisheries, gender, livelihood, food security, local governance, infrastructure, industry, institutes and policies. In 2008, the GoB prepared the Bangladesh Climate Change Strategy and Action Plan (BCCSAP), which was revised in 2009. This comprehensive strategy addresses the challenges of climate change in Bangladesh through six thematic areas:

(1) comprehensive management of disasters;

(2) food security, health and social protection;

(3) infrastructure development;

(4) knowledge and research management;

(5) low-carbon development and mitigation; and

(6) institutional strengthening and capacity building (Dyoulgerov et al., 2011).

The GoB has also developed a number of national policies and plans that deal with the new dimensions of climate change, including the National Agriculture Policy in 1999; National Water Policy in 1999; National Water Management Plan in 2001; Coastal Zone Policy in 2005; and Coastal Development Strategy in 2006. The Draft National Disaster Management Policy in 2008 as well as the Strategic Program for Climate Resilience are based on the BCCSAP and NAPA and represent the first steps in the Pilot Program for Climate Resilience process that began in 2010 (Dyoulgerov et al., 2011).

Although there are no national laws compelling SEA in Bangladesh, SEA has been performed with assistance from donor agencies. In 2006, a country environmental analysis (CEA) was developed as a joint project of the Ministry of Environment and Forests (MoEF) of Bangladesh and World Bank to help the government address and detect environmental restraints on poverty-reducing growth (World Bank, 2006, 2012). CEA, an instrument used by the World Bank to incorporate environmental considerations into national strategies, has been performed in most South Asian countries and has helped guide national strategies and policies toward sustainable development. The GoB began using policy SEA as a decisionmaking tool in late November 2006 at the request of Rajdhani Unnayan Kartripakha (RAJUK) and the Ministry of Housing and Public Works and finalized it in 2007. The GoB worked with the World Bank team to strategize and give direction to the establishment and execution of Detail Area Plans (DAPs) for Dhaka City (Damianova et al., 2008). Another policy SEA included the development and conservation of the Sundarbans, the world's largest mangrove forest (World Bank, 2012). SEA is also reflected in the development of a cumulative environmental assessment for the planning of development in the coastal zone of 
IJCCSM

11,1

Bangladesh: "The SEA for Coastal Embankment Improvement project (ongoing)” (World Bank, 2012).

Summary of findings: The trend of SEA practices in Bangladesh is impact- and institution-centered. Policy SEAs include instruments such as CEA, regional or sectoral environmental assessment and cumulative environmental assessment. In some instances in Bangladesh, SEA has played a significant role in decision-making for improved planning and programming of development proposals. The developed forms of SEA have played a significant role in informing the formulation of polices and planning procedures, such as the integration of environmental concerns in national policies (Box 1) with the application of CEA.

Policy SEA considerations led to mainstreaming of SEA in the Dhaka Metropolitan Development Plan in Bangladesh (Box 2). Through this SEA, the GoB, RAJUK and other government agencies (Department of Environment, Ministry of Housing and Public Works), local government bodies (Dhaka City Corporation, Pourashavas) and sectoral agencies (Dhaka Water Supply and Sewerage Authority, Bangladesh Water Development Board, etc.) obtained a superior appreciation of the environmental challenges and opportunities linked to the execution of urban plans on different levels.

SEA also played an important role in trans-boundary cooperation by facilitating the development of strategies to reduce climate change exposure. As part of efforts toward poverty reduction, biodiversity conservation and institutional change, SEA clarified the functions and roles of agencies, encouraged coordination, and helped build an international partnership between India and Bangladesh (Box 3).

The results of these environmental assessment cases in Bangladesh provide strong evidence of the enormous potential of the application of SEA. The GoB faces some common challenges in both DRR and CCA. Deficiencies in knowledge, scientific understanding and expertise to plan suitable actions in expectation of a hazard are the main limitations. To

\section{Box 1. Instance of SEA for the Integration of Environmental Concerns into National Policies in Bangladesh}

The Bangladesh CEA (2006) was intended to incorporate environmental concerns to develop the environmental content of the Poverty Reduction Strategy Papers and also informed the Indoor Air Pollution Technical Assistance project, the Second Urban Air Quality project and the Dhaka Environment Management project, which is tackling rapid urban growth (World Bank, 2006, 2012).

\section{Box 2. Instance of SEA driving the Dhaka Metropolitan Development Plan in Bangladesh}

The SEA was designed to enable urban development and strategize the Dhaka City DAPs. The assessment prioritized: requisite land use planning by detecting ecosensitive areas; increased planning capacity; and stakeholder engagement in urban planning (World Bank, 2007). 


\section{Box 3. SEA for Bangladesh and West Bengal Sundarbans}

SEA offered strategic guidance for the co-management of natural resources and reduction of poverty via institutional change and cooperation between Bangladesh and India. This SEA also supported bilateral discussions on the communal ecosystem of the Sundarbans between India and Bangladesh (World Bank, 2012).
Strategic environmental assessment

address these knowledge gaps, more cross-sector scientific research on climate change is needed to mainstream the use of SEA to address climate change and DRR.

\section{Strategic environmental assessment case studies}

6.1 Case 1: strategic environmental assessment of Integrated Coastal Zone Management, Portugal: an example of an ecosystem services approach

Analysis and findings: This SEA aided the preparation of the Portuguese Strategy for Integrated Coastal Zone Management (PS-ICZM). Although SEA is not legally required at the policy level in Portugal, the government mandated that the National Water Institute (INAG, the Portuguese authority) develop the PS-ICZM, indicating a recognition of the merits of SEA for strategic decision-making. Ecosystem services were incorporated into the SEA without requiring broad technical exercises, as the SEA did not include a detailed assessment and analysis of the existing ecosystem and services in the coastal zone of Portugal. Rather, the SEA detected and contrasted policy choices in terms of their danger or benefit to ecosystem services at a strategic level, as identified in consultation with major policy stakeholders. This required a consideration of the strategic ecosystem services that could be affected by policy options relevant to the ICZM, including natural coastal dynamics management, especially in vulnerable areas; the maintenance of coastal zone productivity; and the maintenance and conservation of cultural and natural heritage in addition to biodiversity. The SEA proved successful in placing ecosystem services on the agenda. It also facilitated the integration of sustainability and environmental issues with the concepts of strategy and design. Finally, the SEA strongly influenced the PS-ICZM (Partidario, 2011).

\subsection{Case 2: strategic environmental assessment as a tool to integrate climate change} adaptation: a perspective from Nigeria

Analysis and findings: To address the impacts of climate change and unpredictability, Nigeria recognized that there is a need for strong CCA measures based on appropriate tools to reduce adverse effects on environmental quality, the economy, public health, programs and projects (Ogbonna and Albrecht, 2014). In this case, the potential of SEA was assessed and explored, and its application in building rational, informed decisions on the implementation of newly established adaptation programs in Nigeria was proposed. SEA provided a proactive and structured environmental instrument for integrating adaptation to climate change into the formulation of PPPs across related sectors.

\subsection{Case 3: climate adaptation in planning and environmental assessment}

Analysis and findings: DHV (a leading international and consultancy engineering group) developed a Geographic Information System instrument and a publicly accessible website jointly with partners at the Alterra Research Institute and Wageningen University. The instrument maps the risk of and vulnerability to climate change on the local and regional 
IJCCSM 11,1

scales. Climate change with adaptation exigency mapping was subsequently implemented in several Dutch provinces to modernize their spatial planning and long-term construction visions. In addition, DHV began applying climate maps in environmental evaluation projects for spatial planning for urban and municipal areas. By incorporating strategic assessment, climate adaptation strategies and their infrastructural implications, complete direction on the built environment and water was provided to urban architects and spatial planners. The use of spatial data, which were available nationwide, in the SEA was very helpful as a simple, initial means of detecting climate risk vulnerability. This strategy could also be useful for addressing how the implementation of plans or programs may be affected by changes in climate, including the need to adapt to the impact of extreme events and a changing climate (Nuesink, 2011).

6.4 Case 4: integrating a resilience approach with strategic environmental assessment Analysis and findings: This study analyzed the value added to SEA and similar PP (plan/ program) proponents by integrating biodiversity and climate change in SEA as part of incorporating a resilience approach in the European Union. The aim of combining these approaches was to adapt to and combat climate change while halting ecosystem damage and loss of biodiversity. The relationships between a PP and biodiversity and climate change were conceptualized as either a "virtuous" or "vicious" sequence depending on weather and how successfully resilience to future change is integrated. In this study, clarifying examples illustrated how SEA can be utilized to facilitate a virtuous cycle and thus develop more resilient PPs (Nuesink, 2011).

\subsection{Case 5: Mozambique: strategic environmental assessment of a coastal zone}

Analysis and findings: This SEA was conducted by the Ministry for the Coordination of Environmental Affairs (MICOA) of the government of Mozambique with donor funding in 2010. This SEA aimed to reconcile rapid economic growth with the preservation of ecological and biological processes and coastal community wellbeing by improving land-use planning and decreasing potential conflicts arising from various development activities in coastal areas. The key objectives of the SEA were to provide a tool for improving coastal zone land planning, minimizing probable conflicts between major sectors, exploring coastal area resources and supporting sustainable development of the coastal area, taking into account coastal ecosystem services, community livelihoods and conservation of biodiversity. After implementation, the initial report was well-accepted by the main ministries, among which there was consensus on the value of SEA in planning. The format for integrating the guidelines and suggestions in the legal framework was determined by legal experts to ensure an efficient influence on the process of decision-making and utilization in preparing new policies and plans. The value of SEA for planning was recognized by MICOA, and the SEA successfully influenced decision-making processes (Nhachungue and Santos, 2013).

\subsection{Case 6: strategic environmental assessment of the Lisbon metropolitan area regional plan, Portugal: an example of the use of critical decision factors and close collaboration between the planning team and strategic environmental assessment practitioners}

Analysis and findings: The integration of climate change and biodiversity by using a critical decision factor (CDF) approach led to the effective integration of biodiversity and climate change in the Lisbon Metropolitan Area Regional Plan. Based on the results and the collaboration between the planning team and the SEA practitioners, important opportunities were recognized and adopted, e.g. protecting agro-forestry and natural areas, limiting urban 
area expansion and adopting an introductory regional strategy for climate change. The CDF tool was used as part of the SEA to support the assessment of biodiversity and climate change. The resulting CDFs for decision-making provided structure to the assessment and analysis of the risks and opportunities across the SEA. This case is the best example of good practices in incorporating biodiversity and climate change (Sadler and Dusik, 2016).

6.7 Case 7: Vietnam: strategic environmental assessment of the national power development plan 6

Analysis and findings: This SEA was conducted in the context of the Greater Mekong Subregion (GMS) energy sector strategy as a pilot by the Asian Development Bank. The SEA addressed climate change by estimating the impacts of various energy production scenarios on greenhouse gases, with a focus on hydropower. Under the scenarios, a projected reduction of hydropower was offset by an equal increase in the production of thermal power by extending existing plants. The increase in greenhouse gases was identified as very important; the increase in power capability from thermal coal facilities increased carbon dioxide $\left(\mathrm{CO}_{2}\right)$ from power plants and methane $\left(\mathrm{CH}_{4}\right)$ from coal mining. The economic costs associated with increased air pollution were valued as a means of comparing strategic options for power production. This SEA concluded that strategic power production benefits the environment and has greater economic results in terms of energy production (Carew-Reid and Roop, 2013).

\subsection{Case 8: strategic environmental assessment of the Greater Mekong Subregion North-}

South economic corridor development strategy and action plan

Analysis and findings: This SEA was the first trans-boundary SEA in Asia (and one of the first worldwide) to address climate change. It focused on the GMS North-South Economic Corridor running from Kunming (Yunnan Province of China) to Bangkok via Lao People's Democratic Republic (PDR), Myanmar and Thailand. In this SEA, the main partner countries of China, Thailand and Lao PDR conducted a scoping exercise. They identified air pollution as a main strategic issue, "including road/transport, agriculture residues, slash and burn at a large scale and forest fires and greenhouse gases" [Asian Development Bank (ADB), 2008]. The strategic objective was "to minimize air pollution from specific key sectors (e.g. agriculture, industry, transport, domestic) including greenhouse gases" (ADB, 2008). There was less concern and awareness regarding the impacts of climate change on the ecosystem, fisheries, agriculture and forestry (ADB, 2008).

\subsection{Case 9: Ho Chi Minh climate change study}

Analysis and findings: The World Bank, Asian Development Bank and Japan Bank for International Cooperation Institute applied SEA to perform an assessment of climate change impacts on four main coastal cities in GMS in Asia: Bangkok, Manila, Karachi and Ho Chi Minh City (HCMC). Separate studies were conducted for each coastal city, and the following three issues related to adaptation were addressed:

- the expected environmental, economic and social effects of climate change and their probable magnitudes;

- adaptation measures that can address threats as well as related impacts; and

- the main policy concerns for decision-makers in addressing threats.

The HCMC study emphasized the incorporation of adaptation measures in plans for sector development, especially for transport, agriculture and water resources, and in land-use plans 
IJCCSM 11,1

in the city. The study provided a foundation of methods and suggestions for mitigation as a significant part of CCA via a series of SEAs linked to development planning for the city and surrounding provinces (Carew-Reid and Roop, 2013).

The findings and discussions of the above case studies demonstrate that SEA is a useful tool for incorporating CCA concerns into the design and implementation of PPPs at the national and international levels. As an instrument for mainstreaming climate change in development planning, the systematic use of SEA can inform future good development practices.

\section{Addressing challenges}

To successfully integrate DRR in SEA for planning, some important challenges must be addressed, including policy formulation, transparency, capacity building, gaps in data, information and adequate research, funding, institutional frameworks, coordination and collaboration.

\subsection{Policy formulation}

Victor and Agamuthu (2014) noted the absence of legislative frameworks and policy formulation as an important factor in SEA in Tier 4 countries in Asia, such as Sri Lanka and Bangladesh, that have ignored SEA integration and implementation. In Bangladesh, policy formulation is needed to mandate SEA for all development planning at the national, regional and local levels to save present and future generations from the impacts of global and human-induced climate change. The cabinet should formulate policies for SEA adoption and implementation in consultation with the $\mathrm{MoEF}$, other ministries and an environmental Independent Body (IB) comprising non-governmental organizations (NGOs), international donor agencies and research and policy think tanks.

\subsection{Transparency}

A secondary problem in SEA implementation in Bangladesh is the lack of transparency in the decision-making process (Victor and Agamuthu, 2014). A transparent decision-making system is critical for achieving any sustainability-led effort. The adoption of SEA together with an IB will increase transparency in the decision-making system, strengthen PPPmaking procedures and ensure good governance, as expected by the public (Alshuwaikhat et al., 2007).

\subsection{Capacity building}

The SEA team for coastal area planning should have sound skill and capacity for integrating CCA and DRR in SEA. The practical work implemented by SEA teams requires skilled SEA facilitators who can aid the comprehensive assessment process and give suggestions on the approach and methodology (Dusik, 2010). If capacity is inadequate, external support should be sought (Dusik, 2010). Appropriate training workshops at the national and local levels, national guidance paper development and pilot SEA implementation may be required for a better understanding of the integration of DRR and CCA in SEA.

\subsection{Gaps in data, information and adequate research}

Data availability is an important determinant of SEA quality. Key gaps in data, information and research must be addressed to understand and develop an SEA and enhance its relevance to DRR and CCA. Improved baseline data collection, dissemination and analysis 
are needed for updated disaster management responses and sub-national planning. A centralized climate change database that includes hydro-meteorological data, forecasts, warnings and archives should be developed. In Bangladesh, more research work in terms of $\mathrm{DRR}$ is required in coastal areas.

\subsection{Funding}

Given its inherent susceptibility to climate change, there is a significant need for Bangladesh to invest in climate resilience, but available resources are lacking. A sustainable, adequate flow of resources is needed to meet the demands of Bangladesh's climate-exposed communities. Grants and soft loans are potential sources of additional funds to further enhance climate resilience.

\subsection{Institutional framework, coordination and collaboration}

Problems of coordination and collaboration may arise within a government organization or agencies responsible for regional planning and investments during the application of SEA in coastal zones for the integration of CCA and DRR in the planning process. According to Damianova et al. (2008), there are no well-defined systems for coordination or over-arching planning frameworks that would facilitate planning coordination and collaboration among agencies. This limitation may result in failure to integrate DRR and CCA in SEA. To effectively address and mitigate these issues, the $\mathrm{GoB}$ should establish an institutional framework for successful interagency coordination. In Bangladesh, SEA prospects appear to include a more dynamic environmental, legislative and institutional framework that includes obligatory public participation and the establishment of an environmental IB (Victor and Agamuthu, 2014; Alshuwaikhat et al., 2007; Ahammed and Harvey, 2004; Momtaz, 2002).

\section{Conclusion}

The coastal belt populations of Bangladesh are experiencing severe threats from natural hazards such as cyclones, floods, storm surges, salinity intrusion, rough seas, drought and permanent inundation due to sea level rise. The country's coastal management policy covers a broad range of issues, from economic development to ecosystem conservation, but there is no clear option for tackling natural disasters. Earth's climate has changed in the past and is currently changing; further changes in the near future appear unavoidable. Therefore, the GoB must implement a robust adaptation strategy to address the impacts of climate change.

SEA is an important tool that is particularly well suited to exploring different policy options. SEA can model solutions for CCA and test measures for mitigation interactively with stakeholder and decision-makers. There is a need for policy-focused SEA for spatial planning and mid- and long-term development planning at the national, regional and local levels and for PPPs with potentially important environmental impacts. However, SEA is not currently required in Bangladesh. Additional developments in the policy and practice of SEA are needed in Bangladesh to position SEA as an appropriate instrument for assessing and managing all environmental issues, including climate change, at an earlier stage of the planning process. Modifications of national disaster management are needed in Bangladesh, and obligatory SEA implementation will increase awareness of the significance of integrating DRR and CCA in SEA for coastal zone planning.

Moreover, to successfully integrate CCA and DRR in SEA for spatial planning, some challenges must be addressed, including policy formulation, transparency, capacity building, gaps in data, information and research, funding, institutional frameworks and coordination. Previous attempts to increase SEA implementation by providing training to 
IJCCSM 11,1

\section{0}

SEA teams, such as the in use of SEA to facilitate the formulation of policies for climate change, may be expanded by including NGOs and universities. Additional research work is needed in terms of DRR. Research priorities should reflect both key development needs and knowledge gaps and priorities. Among solutions to address these problems, the Bangladesh Bureau of Statistics and the Meteorological Department should become involved in maintaining and collecting data.

\section{Note}

- $\quad C C A$ is defined by the United Nations Framework Convention on Climate Change as "adjustments in natural or human systems in response to actual or expected climatic stimuli or their effects that moderate harm and exploit beneficial opportunities. This can include: adapting development to gradual changes in average temperature, sea level and precipitation; and reducing and managing the risks associated with more frequent, severe and unpredictable extreme weather events" (UNISDR, 2010).

- $\quad D R R$ is the concept and practice of reducing disaster risks through analysis and management of their causal factors. It reduces exposure to hazards, lessens the vulnerability of people and assets, and improves management of the land and environment and preparedness for adverse events (UNISDR, 2009).

- $\quad P P P$ (policy, plan and program): "Policy - a general course of action or proposed overall direction that a government is or will be pursuing and that guides ongoing decision-making; Plan - a purpose forward looking strategy or design, often with coordinated priorities, options and measures that elaborate and implement policy; Program - a coherent organized agenda or schedule of commitments, proposals, instruments and or activities that elaborate and implement policy" (Sadler and Verheem, 1996).

\section{References}

Agee, E., Larson, J., Childs, S. and Marmo, A. (2016), "Spatial redistribution of US Tornado activity between 1954 and 2013", Journal of Applied Meteorology and Climatology, Vol. 55 No. 8, pp. 1681-1697.

Ahmed, M. and Suphachalasai, S. (2014), Assessing the Costs of Climate Change and Adaptation in South Asia, Asian Development Bank, Mandaluyong City, Philippines.

Ahammed, R. and Harvey, N. (2004), "Evaluation of environmental impact assessment procedures and practice in Bangladesh", Impact Assessment and Project Appraisal, Vol. 22 No. 1, pp. 63-78.

Alshuwaikhat, H. (2005), "Strategic environmental assessment can help solve environmental impact assessment failures in developing countries", Environmental Impact Assessment Review, Vol. 25 No. 4, pp. 307-317.

Alshuwaikhat, H.M., Rahman, S.M. and Aina, Y.A. (2007), "The rationale for SEA to overcome the inadequacy of environmental assessment in Bangladesh", The Journal of Environment and Development, Vol. 16 No. 2, pp. 227-246.

Aminuzzaman, S.M. (2014), Final Report. Democratic Local Government Capacity and Natural DisasterBuilding Community Resilience, Bangladesh case study.

An Action Agenda for Sustainable Development (2015), available at: http://unsdsn.org/resources/goalsand-targets/ (accessed 18 August 2015).

Asian Development Bank (ADB) (2008), Greater Mekong Subregion Core Environment Program: Environmental Assessments of Economic Corridors \& Sectors - Implementation Status Report, 
Asian Development Bank, Greater Mekong Subregion Environment Operations Center, Bangkok.

Ayres, J. and Huq, S. (2009), "The value of linking mitigation and adaptation: a case study of Bangladesh", Environment Management, Vol. 43 No. 5, pp. 753-764.

Ayres, J., Huq, S., Wright, H., Faisal, A.M. and Hussain, S.T. (2014), "Mainstreaming climate change adaptation into development in Bangladesh", Climate and Development, Vol. 6 No. 4, pp. 293-305.

Bangladesh Bureau of Statistics (BBS) (2015), Population Density and Vulnerability: A Challenge for Sustainable Development of Bangladesh, Population Monograph: Volume 7, 2015, BBS, Statistics and Informatics Division (SID), Ministry of Planning, GoB.

Bangladesh Environment, Forestry and Climate Change Country Investment Plan (BEFCCCIP) (2016), Second draft, MoEF, GoB.

Carew-Reid, J. and Roop, J. (2013), Strategic environmental assessment as a tool to improve climate change adaptation in the Greater Mekong Subregion, ICEM - International Centre for Environmental Management, Hanoi.

Chowdhury, S.R. (2015), Map of the Coastal Zone of Bangladesh, Institute of Marine Sciences and Fisheries, University of Chittagong.

Christopher, C.W. (2008), "Success by a thousand cuts: the use of environmental impact assessment in addressing climate change", Vermont Journal of Environmental Law, Vol. 9 No. 3, pp. 549-613.

Climate Change Profile: Bangladesh (2016), Advisory Report. The Dutch Sustainability Unit of The Netherlands Commission for Environmental Assessment, Climate Change Profile: Bangladesh.

Damianova, A., Loayza, F., Kishore, S., Minnatullah, K. and Dasgupta, N. (2008), Policies for Mainstreaming Strategic Environmental Assessment in the Urban Development of Greater Dhaka, World Bank.

Dusik, J. (2010), "SEA as a dialogue and planning support tool: lessons from pilot projects in Indonesia", Indonesia-Denmark Environmental Support Program, Phase 2, Component 1, Jakarta.

Dyoulgerov, M., Bucher, A., Zermoglio, F. and Forner, C. (2011), Climate Risk and Adaptation Country Profile, Vulnerability, Risk Reduction and Adaptation to Climate Change, Bangladesh, The World Bank Group, Washington, DC.

Elsner, J.B., Elsner, S.C. and Jagger, T.H. (2015), "The increasing efficiency of tornado days in the United States", Climate Dynamics, Vol. 45 Nos 3/4, pp. 651-659.

Gao, Q. (2017), "Mainstreaming climate change into the EIA procedures: a perspective from China", International Journal of Climate Change Strategies and Management, available at: https://doi. org/10.1108/IJCCSM-04-2016-0040

Geneletti, D., Bagli, S., Napolitano, P. and Pistocchi, A. (2007), "Spatial decision support for strategic environmental assessment of land use plans. A case study in Southern Italy", Environmental Impact Assessment Review, Vol. 27 No. 5, pp. 408-423.

Ghofrani, Z., Sposito, V. and Faggian, R. (2017), "A comparative review of blue-green infrastructure concepts", International Journal of Environment and Sustainability, Vol. 6 No. 1, pp. 15-36.

Hegazy, I.R. (2015), "Integrating strategic environmental assessment into spatial planning in Egypt", Environmental Development, Vol. 15, pp. 131-144.

Hossain, M.L., Hossain, M.K. and Das, S.R. (2009), "Vulnerability of Bangladesh to natural and anthropogenic disasters", available at: www.academia.Edu/828160/Vulnerability_of _Bangladesh_to_Natural_and_Anthropogenic_Disasters

IPCC (2007), "Summary for policy makers", in Parry, M.L., Canziani, O.F., Palutikof, J.P., van der Linden, P.J. and Hanson, C.E. (Eds), Climate Change 2007: Impacts, Adaptation and Vulnerability. Contribution of Working Group II to the Fourth Assessment Report of the Intergovernmental Panel on Climate Change, Cambridge University Press, Cambridge, pp. 7-22. 
IJCCSM 11,1

IPCC (2014), "Climate change 2014: synthesis report”, Contribution of Working Groups I, II and III to the Fifth Assessment Report of the IPCC, IPCC, Geneva.

Islam, M.R. (Ed.) (2004), Where Land Meets the Sea: A Profile of the Coastal Zone of Bangladesh, University Press Limited, Dhaka.

Islam, M.R. (2008), "Towards institutionalization of global ICZM efforts", in Krishnamurthy, R.R. (Ed.), Integrated Coastal Zone Management, Research Publishing Services, Singapore, pp. 23-34.

Kreft, S., Eckstein, D., Dorsch, L. and Fischer, L. (2015), Briefing Paper, Global Climate Risk Index 2016. Who Suffers Most from Extreme Weather Events? Weather-Related Loss Events in 2014 and 1995 to 2014, Germanwatch.

Leary, N. (2012), Climate Change and Adaptation, Earthscan.

Momtaz, S. (2002), "Environmental impact assessment in Bangladesh: a critical review", environment", Impact Assessment Review, Vol. 22 No. 2, pp. 163-179.

MoWR (2006), Coastal Development Strategy, Ministry of Water Resources (MoWR) Government of the People's Republic of Bangladesh, Dhaka.

NAPA (2005), National Adaptation Program of Action, MoEF, GoB.

Nhachungue, E. and Santos, L. (2013), "Mozambique-SEA of the coastal zone", Report on the Africa regional workshop on SEA and green economy, 17-18 January 2013, Lusaka, Zambia, organized by the Ministry of Lands, Natural Resources and Environmental Protection, Zambia, Zambia Environmental Protection Agency (ZEMA), OECD DAC Environet SEA Task Team and the Finnish Environment Institute (SYKE).

Noble, B.F. and Storey, K. (2001), "Towards a structured approach to a strategic environmental assessment", Journal of Environmental Assessment Policy and Management, Vol. 03 No. 4, pp. 483-508.

Nuesink, J. (2011), "Climate adaptation in planning and environmental assessment", IAIA (The International Association for Impact Assessment). SEA implementation and practice: Making an Impact?, Special Conference on SEA, Prague, Czech Republic, 21-23 September 2011.

OECD/DAC (2010), Strategic Environmental Assessment and Adaptation to Climate Change, OECD publications, p. 31.

Ogbonna, C.U. and Albrecht, E. (2014), "Strategic environmental assessment as a tool to integrate climate change adaptation: a Perspective for Nigeria", in Leal Filho, W. (Ed.), Handbook of Climate Change Adaptation, Springer, Berlin, Heidelberg, pp. 1-19.

Partidario, M.R. (2011), TEEB Case: SEA for Including Ecosystem Services in Coastal Management, Portugal, available at: www.TEEBweb.org

Parvin, G.A., Ahsan, S.M.R. and Shaw, R. (2010), "Community based coastal zone management in Bangladesh", in Shaw, R. and Krishnamurthy, R.R. (Eds), Communities and Coastal Zone Management, Research Publishing Services, Singapore, pp. 165-184.

Pramanik, M.A.H. (1983), "Remote sensing application to coastal morphological investigations in Bangladesh", PhD Thesis, Jahangirnagar University.

Quam, V.G.M., Rocklöv, J., Quam, M.B.M. and Lucas, R.A.I. (2017), "Assessing greenhouse gas emissions and health co-benefits: a structured review of lifestyle-related climate change mitigation strategies", International Journal of Environmental Research and Public Health, Vol. 14 No. 5, pp. 468, doi: 10.3390/ijerph14050468.

Roberts, D. (2008), "Thinking globally acting locally - institutionalizing climate change at the local government level in Durban, South Africa", Environment and Urbanization, Vol. 20 No. 2, pp. 521-537.

Sadler, B. (1999), "Environmental sustainability assessment and assurance", in Petts, J. (Ed.), Handbook of Environmental Impact Assessment, Blackwell, London, pp. 12-32.

Sadler, B. and Dusik, J. (2016), SEA of Lisbon Metropolitan Area Regional Plan, Portugal-an Example of Using Critical Decision Factors and Close Collaboration between Plan-Makers and SEA 
Practitioners. European International Experiences of Strategic Environmental Assessment. Recent Progress and Future Prospects, Earthscan, London and New York.

Sadler, B. and Verheem, R. (1996), "Strategic environmental assessment 53: status, challenges and future directions. Ministry of housing, spatial planning and the environment", The Netherlands, and the International Study of Effectiveness of Environmental Assessment.

Smutný, M. (2014), Czech Republic: SEA in Spatial Planning, October 8th, 2014, Integra Consulting Ltd, Minsk.

Stoeglehner, G. (2010), "Enhancing SEA effectiveness: lesson learnt from Austrian experiences in spatial planning", Impact Assessment and Project Appraisal, Vol. 28 No. 3, pp. 217-231.

Susilowardhani, A. (2014), "The potential of strategic environmental assessment to address the challenges of climate change to reduce the risks of disasters: a case study from Semarang", Procedia - Social and Behavioral Science, Vol. 135, pp. 3-9.

UNISDR (2009), Global Assessment Report on Disaster Risk Reduction, United Nations Secretariat to the International Strategy for Disaster Reduction (ISDR), Geneva.

UNISDR (2010), Local Governments and Disaster Risk Reduction: Good Practices and Lessons Learned, United Nations Secretariat to the International Strategy for Disaster Reduction (ISDR), Geneva, p. 86.

Victor, D. and Agamuthu, P. (2014), "Policy trends of strategic environmental assessment in Asia", Environmental Science and Policy, Vol. 41, pp. 63-76.

Wang, K., Zhong, S., Wang, X., Wang, Z., Yang, L., Wang, Q., Wang, S., Sheng, R., Ma, R., Lin, S., Liu, W., Zu, R. and Huang, C. (2016), "Assessment of the public health risks and impact of a tornado in Funing, China", International Journal of Environmental Research and Public Health, Vol. 14 No. 10, p. 1201.

Walsham, M. (2010), Assessing the Evidence: environment, Climate Change and Migration in Bangladesh, International Organization for Migration (IOM).

Willekens, M., Maes, F. and Malfait, E. (2011), CLIMAR - Evaluation of Climate Change Impacts and Adaptation Responses for Marine Activities. Subdocument: Adaptation to Climate Change and Strategic Environmental Assessment. Report Prepared in the Framework of the CLIMAR Project for the Belgian Science Policy, Contract SD/NS/01A, Maritime Institute, Gent, p. 62.

World Bank (2006), Main Report, World Bank, Washington, DC, available at: http://documents. worldbank.org/curaated/en/2006/08/7121840/bangladesh-country-envir-onental-analysisvol-1-2-mainreport (accessed 23 March 2016).

World Bank (2007), Dhaka Metropolitan Development Plan: Strategic Environmental Assessment, World Bank, Washington, DC, available at: http://documents.worldbank.org/curated/en/2007/ 07/17207304/dhaka-metropolitan-development-plan-strategic-environmental-assessment (accessed 15th September 2015).

World Bank (2012), in Loayza, F. (Ed.), Strategic Environmental Assessment in the World Bank Learning from Recent Experience and Challenges, The World Bank Group, Washington, DC.

For instructions on how to order reprints of this article, please visit our website:

www.emeraldgrouppublishing.com/licensing/reprints.htm

Or contact us for further details: permissions@emeraldinsight.com 